\title{
Implementasi Metode Mind Mapping Dalam Pembelajaran Bahasa Inggris Aspek Writing Untuk Meningkatkan Hasil Belajar Siswa
}

\author{
Yulyanti Abdullah Luawo \\ Guru SMP Negeri 1 Buntulia Gorontalo \\ yulyanti@gmail.com
}

Received: 04 Januari 2021; Revised: 26 Februari 2021; Accepted: 28 April 2021

DOI: http://dx.doi.org/10.37905/aksara.7.2.491-506.2021

\begin{abstract}
Abstrak
Penelitian ini bertujuan untuk mengetahui peningkatan hasil belajar siswa pada mata pelajaran bahasa inggirs aspek writing melalui penerapan metode pembelajaran Mind Mapping pada siswa. Jenis penelitian ini merupakan Penelitian Tindakan Kelas (PTK). Subjek dalam penelitian ini adalah siswa kelas VII B SMP Negeri 1 Buntulia yang berjumlah 25 orang yang terdiri dari 9 siswa laki - laki dan 16 siswa perempuan. Penelitian dilaksanakan 2 siklus. Pengambilan data dalam penelitian ini dilakukan dengan menggunakan tes hasil belajar, lembar pengamatan observasi guru dan pengamatan aktivitas siswa. Berdasarkan hasil analisis data menunjukan bahwa terjadi peningkatan hasil belajar siswa pada mata pelajaran bahasa inggirs aspek writing di kelas VII B SMP Negeri 1 Buntulia melalui penerapan metode pembelajaran Mind Mapping. Hasil tes pada silkus I, terdapat 16 siswa yang sudah tuntas hasil belajarnya (64\%) dan yang tuntas belajar 9 siswa (36\%). Kategori ketuntasan belajar siswa pada pembelajaran secara klasikal adalah jika mencapai $80 \%$ sehingga ketuntasan belajar siswa secara klasikal pada siklus I belum tercapai. Pada siklus II siswa tidak tuntas belajarnya adalah 3 siswa (12\%) dari 25 siswa dan yang tuntas belajarnya adalah 22 siswa (88\%). Hal ini berarti ketuntasan klsikal sudah tercapai Dengan demikian, penerapan metode pembelajaran mind mapping sangat efektif digunakan untuk meningkatkan hasil belajar siswa pada mata pelajaran bahasa inggirs aspek writing
\end{abstract}

Kata Kunci: Mind Mapping, Hasil Belajar Siswa

\begin{abstract}
This study aims to determine the improvement of student learning outcomes in the English subject in the writing aspect through the application of the Mind Mapping learning method to students. This type of research is a Classroom Action Research (PTK). The subjects in this study were 25 students of class VII B SMP Negeri 1 Buntulia consisting of 9 male students and 16 female students. The research was conducted in 2 cycles. Data retrieval in this study was carried out using learning outcomes tests, teacher observation sheets and student activity observations. Based on the results of data analysis, it shows that there has been an increase in student learning outcomes in the writing aspect of English subjects in class VII B SMP Negeri 1 Buntulia through the application of the Mind Mapping learning method. The test results in silkus I, there were 16 students who had completed their learning outcomes (64\%) and 9 students who had completed their studies (36\%). The category of student learning completeness in classical learning is if it reaches $80 \%$ so that classical student learning completeness in the first cycle has not been achieved. In cycle II students who did not complete their learning were 3 students (12\%) of 25 students and 22 students who had completed their studies (88\%). This means that classical completeness has been achieved.
\end{abstract}

Keywords: Mind Mapping, Student Learning Outcomes 


\section{PENDAHULUAN}

Mata pelajaran Bahasa Inggris mempunyai karakteristik yang berbeda dengan mata pelajaran lain. Perbedaan ini terletak pada fungsi bahasa sebagai alat komunikasi. Selain diperlukan penguasaan kosa kata dan tata bahasa, juga diperlukan keterampilan dalam mengaplikasikannya dalam kegiatan komunikasi, baik lesan maupun tulis (Depdiknas, 2006:2). Pada pembelajaran kompetensi atau aspek writing, yang tujuan akhirnya adalah memproduk atau menghasilkan tulisan atau teks baik fungsional maupun monolog berdasarkan genre atau jenis teks, diharapkan siswa dapat memahami ciri-ciri dari suatu teks, dan dapat mengekspresikannya dengan kosa kata dan tata bahasa yang benar

Di SMP Negeri 1 Buntulia, banyak siswa khususnya kelas VII B yang merasa kesulitan dalam mengikuti pelajaran Bahasa Inggris khususnya pada aspek writing, hal ini mengakibatkan hasil belajar siswa kurang dari KKM yang telah ditetpkan. Sebagai contoh, pada waktu diberi tugas menulis teks monolog berbentuk descriptive yang sudah ditentukan tema atau judulnya, kebanyakan siswa tidak segera melaksanakan, bahkan malah ditinggal ngobrol dengan teman di dekatnya. Nampak tidak serius dan malas mengerjakannya. Padahal langkahlangkah menulis descriptive sudah pernah dipelajari, seperti pola kalimat simple present tense, contoh-contoh cara membuat kalimatnya, menentukan kosa kata yang akan digunakan, yang berkaitan dengan tema yang sedang dipelajari serta generic structurenya juga sudah diberikan. Contoh descriptive text pun sudah diberikan dalam pembelajaran aspek reading.

Ada kemungkinan kesulitan itu dikarenakan bahwa selama ini, kebanyakan siswa menganggap mata pelajaran Bahasa Inggris sebagai momok atau mata pelajaran yang sulit dan tidak menarik. Karena sulit dan tidak menarik, siswa cenderung tidak suka, malas dan ingin menghindarinya. Akibatnya, siswa malas mengikuti pelajaran itu atau kurang serius dan malas mengerjakan tugas yang dibebankan oleh gurunya. Kamus, sebagai sarana pendukung yang penting dalam belajar bahasa asing, juga jarang yang memilikinya. Ada yang memiliki, tapi malas membawanya karena berat. Itu semua terjadi karena kurangnya motivasi dan kurang minatnya terhadap mata pelajaran Bahasa Inggris. Ada siswa yang sudah mulai menulis, kemudian macet di tengah jalan, hal ini dikarenakan kesulitan memunculkan ide, padahal tema atau judul sudah ditentukan. Akibatnya tugas writing banyak yang tidak dikumpulkan. Dan hal ini berpengaruh juga pada hasil belajar yang mereka dapatkan setelah pembelajaran

Berdasarkan permasalahan-permasalahan tersebut di atas, peneliti mencoba melakukan suatu penelitian tindakan kelas (PTK) dengan menerapkan metode pembelajaran mind mapping untuk mengatasi sebagian dari permasalahanpermasalahan itu. Dengan digunakannya metode ini diharapkan para siswa menjadi lebih tertarik untuk mengikuti mata pelajaran Bahasa Inggris.

\section{KAJIAN TEORI}

\section{Hasil Belajar}

Menurut Gagne dan Bringgs (dalam Suprihatiningrum, 2013 : 37) hasil belajar adalah kemampuan - kemampuan yang dimiliki oleh siswa sebagai akibat perbuatan belajar yang dapat diamati melalui penampilan siswa. Sedangkan 
menurut Dimyati (2010: 10) hasil belajar merupakan hasil dari suatu interaksi tindak belajar dan mengajar. Dari sisi guru, tindak mengajar di akhiri dengan proses evaluasi hasil belajar. Dari sisi siswa, hasil belajar merupakan berakhirnya pengajaran dari punjak proses belajar. Dan menurut Sudjana (2002: 3), hasil belajar juga merupakan perubahan tingkah laku siswa setelah melalui proses pembelajaran. Semua perubahan dari proses pembelajaran merupakan suatu hasil belajar dan mengakibatkan manusia berubah dalam sikap dan tingkah lakunya.

Maka dari uraian dia atas dapat di simpulkan bahwa hasil belajar adalah kemampuan - kemampuan yang di miliki siswa setelah menerima pengalaman belajarnya. Kemampuan tersebut mencakup aspek kognitif, afektif dan psikomotorik

Berdasarkan teori teori taksonomi Bloom hasil belajar dalam rangka studi dicapai melalui tiga kategori ranah antara kognitif, afektif dan psikomotorik.

a. Ranah kognitif

Berkenaan dengan hasil belajar intelektual yang terdiri dari enam aspek yaitu pengetahuan, pemahaman, penerapan, analisis, sintesis dan penilaian

b.Ranah afektif

Berkenaan dengan sikap dan nilai, ranah afektif meliputi lima jenjang kemampuan yaitu menerima, manjawab atau reaksi, menilai organisasi dan karakteristik dalam satu nilai atau kompleks nilai.

c. Ranah psikomotorik

Meliputi keterampilan motorik, manipulasi benda - benda, koordinasi neuromusculer (menghubungkan, mengamati)

\section{Hasil Belajar}

Menurut Dyah Retno (2011:22) Mind mapping adalah metode yang mempelajari konsep pikiran yang didasarkan pada kerja otak menyimpan informasi. Otak tidak menyimpan informasi dalam kotak -kotak sel saraf yang berjejer rapi melainkan dikumpulkan pada sel - sel saraf yang bercabang. Selain itu otak hanya mampu mengingat informasi berupa kata kunci dan gambar. Berdasarkan hal tersebut maka Tony Buzzan menciptakan mind mapping

Menurut Bobbi Deporter (2004: 175) mind mapping adalah sebuah metode mencatat yang baik membantu mengingat perkataan dan bacaan, meningkatkan pemahaman terhadap materi, membantu mengorganisasi materi, dan memberikan wawasan baru. Peta pikiran memudahkan kita mengingat banyak informasi, catatan yang di buat membentuk sebuah pola yang saling berkaitan dengan topik utama ditengah dan perincian menjadi cabang - cabangnya. Peta pikiran yang terbaik adalah peta pikiran yang warna -warni dan menggunakan banyak gambar dan simbol

Sedangkan menurut Tony Buzan (2006: 103) mind mapping merupakan teknik pemetaan pikiran untuk membantu membuka seluruh potensi dan kapasitas otak yang masih tersembunyi. Pemetaan pikiran ini akan melibatkan kedua sisi otak secara bersamaan, yakni otak kanan dan kiri. Metode ini mempermudah memasukkan informasi dari dalam otak. Menurut Sugiarto lwan (2004:75) mind mapping merupakan metode pembelajaran dengan cara meringkas bahan pembelajaran dengan memproyeksikan masalah yang dihadapi dengan bentuk peta atau grafik sehingga siswa dapat lebih mudah memahami pembelajaran 
Berdasarkan pengertian diatas, maka dapat disimpulkan bahwa mind mapping adalah sebuah cara yang kreatif yang dapat menyimpulkan suatu materi pelajaran dengan mengubah teknik -teknik verbal dengan teknik visualisasi gambar sehingga siswa lebih mudah memahami serta mengingat materi pelajaran berikut:

Adapun langkah - langkah dalam membuat mind mapping adalah sebagai

a. Mulailah dari bagian tengah yang kosong karena memulai dari tengah memberi kebebasan pada otak untuk menyebar kesegala arah dan mengungkapkan dirinya dengan lebih bebas dan alami.

b. Gunakan gambar atau foto untuk ide sentral. Sebab sebuah gambar bermakna seribu kata dan membantu seseorang mengunakan imajinasi. Sebuah gambar sentral akan menarik, membuat tetap terfokus membantu berkonsentrasi dan mengaktifkan otak

c. Gunakan warna. Bagi otak warna sama menariknya dengan gambar. Warna membuat mind mapping lebih hidup, menambahkan energi kepada pemikiran yang kreatif dan menyenangkan.

d. Hubungkan cabang - cabang utama ke gambar pusat dan hubungkan cabang cabang tingkat dua dan tiga ke tingkat satu dan dua, dan seterusnya. Otak bekerja menurut asosiasi otak senang mengaitkan dua atau tiga dan atau empat hal sekaligus. Bila menghubungkan cabang akan lebih mudah mengerti dan mengingat.

e. Buatlah garis hubung yang melengkung.

f. Gunakan satu kata kunci untuk setiap garis.

g. Gunakan gambar yang sesuai pada setiap cabang untuk memperjelas kata kunci

\section{METODE PENELITIAN}

Adapun langkah - langkah perencanaan penelitian tindakan kelas ini menggunakan model penelitian tindakan dari Kemmis dan Taggart sebagai berikut

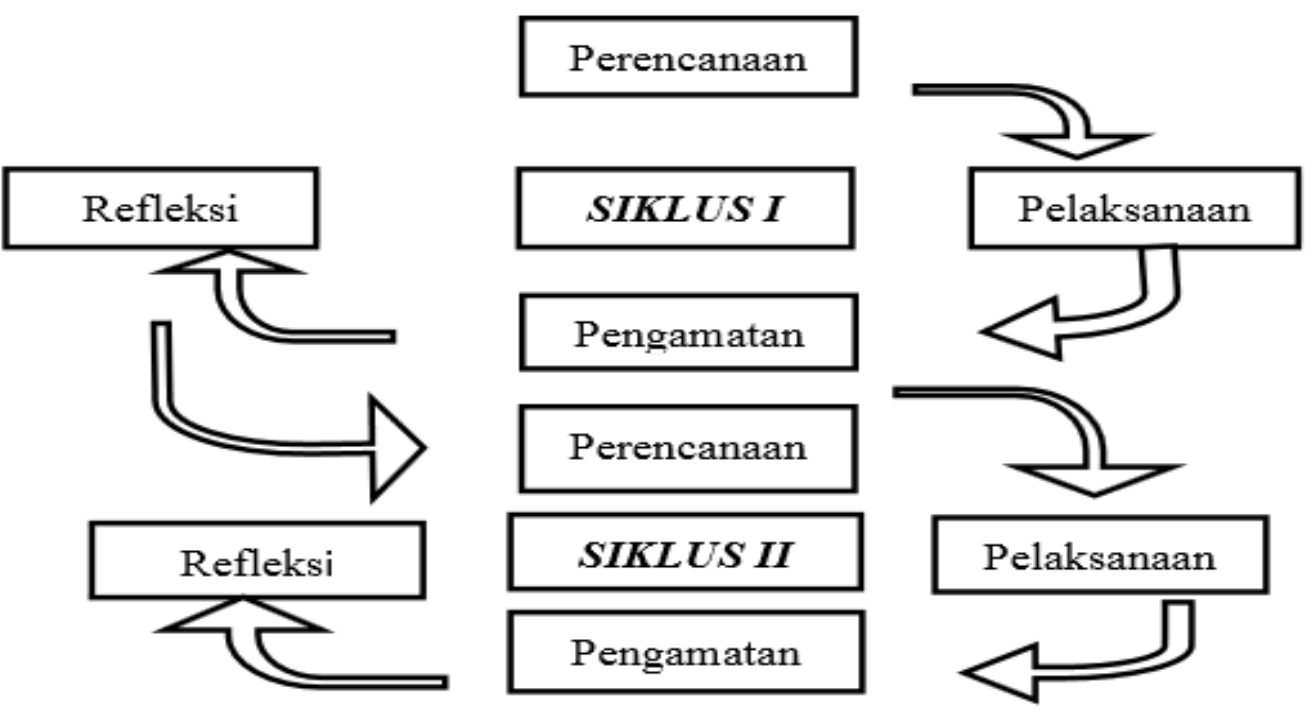

Gambar 1 Skema Desain Penelitian 
1. Perencanaan, sebelum mengadakan penelitian menyusun rumusan masalah, tujuan dan membuat rencana tindakan termasuk didalamnya instrument penelitian dan perangkat pembelajaran.

a. Menyusun materi yang akan diajarkan

b. Menyusun rencana pelaksanaan pembelajaran (RPP)

c. Menyusun alat evaluasi (Tes)

d. Menyusun lembaran observasi untuk guru dan siswa

e. Menyiapkan lembar kerja siswa

2. Pelaksanaan, meliputi tindakan yang dilakukan oleh peneliti sebagai upaya membangun pemahaman konsep siswa serta mengamati hasil atau dampak dari diterapkannya metode mind mapping.

a. Guru mengabsen siswa

b. Guru mencapai tujuan pembelajaran

c. Guru menjelaskan materi yang diajarkan dengan menggunakan metode mind mapping

d. Guru mempersilahkan siswa bertanya terkait dengan materi yang akan diajarkan.

e. Guru menanggapi jawaban dan pertanyaan siswa

f. Guru memberikan tes / evaluasi

3. Pengamatan, meliputi pengamatan terhadap kegiatan yang dilakukan oleh peneliti danjuga siswa dalam proses pembelajaran dengan menggunakan metode mind mapping.

4. Refleksi, melihat dan mempertimbangkan hasil atau dampak dari tindakan yang dilakukan berdasarkan lembar pengamatan yang diisi oleh pengamat

Subjek dari penelitian ini adalah Siswa Kelas VII B SMP Negeri 1 Buntulia Tahun Ajaran 2017/2018 yang terdiri dari 25 siswa. 9 siswa laki - laki dan 16 siswa perempuan. Subjek ini dipilih karena nilai pembelajaran Bahasa Inggris pada kelas tersebut sebagian besar masih tergolong rendah, siswa kurang minat dan aktif dalam proses pembelajaran dibandingkan dengan siswa kelas lainnya.

Adapun teknik pengumpulan data yang peneliti gunakan adalah sebagai berikut:

\section{Observasi Kemampuan Guru}

Lembar observasi ini digunakan untuk mengamati kegiatan guru (peneliti) pada saat proses pembelajaran berlangsung. Observasi dilakukan oleh teman sejawat dengan cara melakukan pengamatan mengenai pelaksanaan pembelajaran melalui penggunaan metode Mind Mapping

\section{Observasi Aktivitas Siswa}

Lembar observasi ini digunakan untuk mengamati kegiatan siswa pada saat proses pembelajaran berlangsung. Observasi dilakukan guru (peneliti) dengan cara melakukan pengamatan mengenai pelaksanaan pembelajaran melalui penggunaan Metode Mind Mapping

\section{Tes Hasil Belajar}

Tes ini dilakukan sesudah proses pembelajaran berlangsung dengan melihat kriteria keberhasilan pembelajaran sejauh mana siswa berhasil menguasai pembelajaran. Manfaat tes ini untuk mengukur hasil belajar siswa dalam aspek kognitif, atau tingkat penguasaan materi pembelajaran 
Data yang telah terkumpul selanjutnya diolah dengan menggunakan statistik. Tahap - tahap analisis data adalah sebagai berikut:

\section{Analisis Kemampuan Guru}

Data kemampuan guru diperoleh dari lembar pengamatan yang diisi selama proses pembelajaran berlangsung. Data ini dianalisis dengan menggunakan rumus persentase:

Keterangan :

$$
P=\frac{f}{N} \times 100 \%
$$

$\mathrm{P}=$ Angka Persentase

$\mathrm{F}=$ Frekuensi kemampuan guru

$\mathrm{N}$ = Jumlah kemampuan keseluruhan

Tabel 1

Skor rata - rata kemampuan guru

\begin{tabular}{|c|c|}
\hline Skor Rata - Rata Kemampuan Guru & Kategori \\
\hline $0 \% \leq \mathrm{TKG}<60 \%$ & Tidak Baik \\
\hline $60 \% \leq \mathrm{TKG}<70 \%$ & Kurang Baik \\
\hline $70 \% \leq \mathrm{TKG}<80 \%$ & Cukup \\
\hline $80 \% \leq \mathrm{TKG}<90 \%$ & Baik \\
\hline $90 \% \leq \mathrm{TKG}<100 \%$ & Sangat Baik \\
\hline
\end{tabular}

Ket :

$\mathrm{TKG}=$ Tingkat Kemampuan Guru

\section{Analisis Aktifitas Siswa}

Data aktivitas siswa diperoleh dari lembar pengamatan yang diisi selama proses pembelajaran berlangsung. Data ini dianalisis dengan menggunakan rumus persentase:

Keterangan :

$$
P=\frac{f}{N} \times 100 \%
$$

$\mathrm{P}=$ Angka Persentase

$\mathrm{F}=$ Frekuensi kemampuan guru

$\mathrm{N}=$ Jumlah kemampuan keseluruhan

Tabel 2

Skor rata - rata kemampuan siswa

\begin{tabular}{|c|c|}
\hline Skor Rata - Rata Kemampuan Siswa & Kategori \\
\hline $0 \% \leq \mathrm{TKG}<60 \%$ & Tidak Baik \\
\hline $60 \% \leq \mathrm{TKG}<70 \%$ & Kurang Baik \\
\hline $70 \% \leq \mathrm{TKG}<80 \%$ & Cukup \\
\hline $80 \% \leq \mathrm{TKG}<90 \%$ & Baik \\
\hline $90 \% \leq \mathrm{TKG}<100 \%$ & Sangat Baik \\
\hline
\end{tabular}

Ket :

TKS = Tingkat Kemampuan Siswa

\section{Analisis Hasil Belajar Siswa}

Analisis ini dilakukan untuk mengetahui apakah terjadi peningkatan hasil belajar melalui penerapan metode mind mapping, dianalisis menggunakan 
klasifikasi penelitian yaitu dengan menentukan skor pada setiap indikator sesuai dengan pedoman penskoran yang telah ditetapkan yaitu menghitung presentase rata - rata tiap indikator untuk mengetahui ketuntasan klasikal dan daya serap klasikal dari setiap indikator dengan menggunakan rumus berikut:

Keterangan :

$$
K S=\frac{N T}{N} \times 100 \%
$$

$\mathrm{KS}=$ Ketuntasan Klasikal

NT = Jumlah Siswa Yang Tuntas

$\mathrm{N}$ = Jumlah siswa keseluruhan

\section{PEMBAHASAN}

\section{Siklus I}

Observasi dilakukan terhadap kemampuan guru, aktivitas siswa dan hasil belajar siswa, serta mencatat hal - hal yang terjadi selama pelaksanaan pembelajaran.

1) Observasi Kemampuan Guru

\begin{tabular}{|c|c|c|c|}
\hline No & Aspek yang Diamati & Nilai & Keterangan \\
\hline 1 & $\begin{array}{l}\text { Pendahuluan: } \\
\text { Kemampuan melakukan apersepsi kepada siswa sebelum } \\
\text { menyampaikan tujuan pembelajaran }\end{array}$ & 3 & Baik \\
\hline 2 & $\begin{array}{l}\text { Kemampuan memotivasi siswa dengan } \\
\text { mengemukakan kegunaan materi yang akan } \\
\text { dipelajari }\end{array}$ & 3 & Baik \\
\hline 3 & $\begin{array}{l}\text { Kemampuan menyampaikan tujuan pembelajaran dan } \\
\text { menginformasikan pembelajaran melalui metode mind } \\
\text { mapping }\end{array}$ & 2 & Cukup \\
\hline 4 & $\begin{array}{l}\text { Kegiatan inti: } \\
\text { Kemampuan menjelaskan materi dengan menggunakan } \\
\text { metode mind mapping }\end{array}$ & 3 & Baik \\
\hline 5 & $\begin{array}{l}\text { Kemampuan memberi kesempatan kepada siswa untuk } \\
\text { bertanya. }\end{array}$ & 4 & Sangat Baik \\
\hline 6 & Kemampuan menghargai berbagai pendapat siswa & 4 & Sangat Baik \\
\hline 7 & $\begin{array}{l}\text { Kemampuan memberikan penguatan kepada } \\
\text { siswa }\end{array}$ & 3 & Baik \\
\hline 8 & $\begin{array}{l}\text { Kemampuan guru memberikan pertanyaan } \\
\text { kepada siswa. }\end{array}$ & 2 & Cukup \\
\hline 9 & $\begin{array}{l}\text { Kemampuan mengarahkan siswa untuk } \\
\text { menyelesaikan tugas secara kelompok }\end{array}$ & 3 & Baik \\
\hline 10 & Kemampuan guru menguasai kelas & 2 & Cukup \\
\hline 11 & $\begin{array}{l}\text { Penutup : } \\
\text { Kemampuan guru menyimpulkan terhadap } \\
\text { materi yang telah diajarkan }\end{array}$ & 4 & Sangat Baik \\
\hline 12 & Kemampuan mengalokasikan waktu & 3 & Baik \\
\hline 13 & Adanya interaksi antara siswa dan guru & 4 & Sangat Baik \\
\hline \multicolumn{2}{|c|}{ Jumlah } & \multicolumn{2}{|r|}{41} \\
\hline & Nilai Presentase & \multicolumn{2}{|r|}{$78 \%$} \\
\hline & Kategori & \multicolumn{2}{|r|}{ Cukup } \\
\hline
\end{tabular}

Tabel 3

Lembar Observasi Kemampuan Guru Pada Siklus I 
Berdasarkan Tabel 3 menunjukkan bahwa kegiatan pembelajaran melalui metode mind mapping mendapatkan skor persentase $78 \%$ yang berada pada kategori cukup. Data di atas juga menjelaskan bahwa masih ada beberapa kemampuan guru yang masih rendah dan perlu ditingkatkan, yaitu diantaranya guru belum mampu menyampaikan tujuan pembelajaran dan menginformasikan pembelajaran melalui metode mind mapping dikarenakan lupa dan belum mampu memberikan pertanyaan kepada siswa karena guru kurang maksimal memberikan pembelajaran dengan menggunakan metode mind mapping, serta belum mampu menguasai kelas dengan baik

2) Observasi Aktivitas Siswa

Pada tahap ini adalah kegiatan mengamati aktivitas siswa pada saat pembelajaran berlangsung, dari awal sampai akhir untuk setiap pertemuan. Hasil pengamatan aktivitas siswa Dapat dilihat pada tabel 4 berikut:

Tabel 4

Lembar Observasi Aktivitas Siswa Siklus I

\begin{tabular}{|c|l|c|c|}
\hline No & \multicolumn{1}{|c|}{ Aspek yang Diamati } & Nilai & Keterangan \\
\hline 1 & Mendengarkan/memperhatikan penjelasan guru & 3 & Baik \\
\hline 2 & $\begin{array}{l}\text { Mengajukan pertanyaan yang berhubungan } \\
\text { dengan materi }\end{array}$ & 3 & Baik \\
\hline 3 & Antusias siswa dalam belajar & 3 & Baik \\
\hline 4 & $\begin{array}{l}\text { Pengerjaan LKS yang diberikan oleh guru } \\
\text { Cukup }\end{array}$ & 2 & Cukup \\
\hline 6 & $\begin{array}{l}\text { Presentasi siswa terhadap hasil tugas kelompok } \\
\text { diajarkan kesimpulan tentang materi yang telah }\end{array}$ & 2 & Baik \\
\hline 7 & $\begin{array}{l}\text { Perilaku yang tidak relevan dengan KMB } \\
\text { Seperti: melamun, jalan - jalan di kelas, } \\
\text { membaca buku/mengerjakan tugas mata } \\
\text { pelajaran lain, bermain - main dengan teman dan } \\
\text { lain - lain J }\end{array}$ & 3 & Baik \\
\hline \multicolumn{2}{|c|}{ Kumlah } & \multicolumn{2}{c|}{$67,85 \%$} \\
\hline
\end{tabular}

Berdasarkan Tabel 4 dapat dilihat bahwa aktivitas siswa selama proses pembelajaran melalui metode mind mapping pada siklus I memperoleh hasil kurang, yaitu diantaranya masih kurang mengerti bagaimana cara pengerjaan LKS yang benar dan juga cara persentase siswa yang tidak sesuai dengan arahan guru. Nilai presentase aktivitas siswa pada siklus I ini memperoleh hasil 67,85\% yang termasuk dalam kategori kurang.

3) Hasil belajar Siswa Pada Siklus I

Di akhir pembelajaran Siklus I, peneliti memberikan tes untuk mengetahui ketuntasan belajar siswa, dengan kriteria ketuntasan minimal yang diterapkan di SMP Negeri 1 Buntulia minimal 70. Hasil tes belajar pada Siklus I dapat dilihat pada tabel dibawah ini

Tabel 5 
Daftar Nilai Hasil Belajar Siswa Siklus I

\begin{tabular}{|c|c|c|c|}
\hline No & Nama & Nilai & Keterangan \\
\hline 1 & Aslan Djumaati & 80 & Tuntas \\
\hline 2 & Abd Rahim Goi & 75 & Tuntas \\
\hline 3 & Audi Masayu Dauna & 50 & Belum Tuntas \\
\hline 4 & Bunga Bajuani & 70 & Tuntas \\
\hline 5 & Deis Balu & 90 & Tuntas \\
\hline 6 & Elsa Tantu & 70 & Tuntas \\
\hline 7 & Fitri Hulopi & 75 & Tuntas \\
\hline 8 & Ingki Umar & 50 & Belum Tuntas \\
\hline 9 & Indri Umar & 65 & Belum Tuntas \\
\hline 10 & Kasim Bagi & 80 & Tuntas \\
\hline 11 & Lutvia Adam & 90 & Tuntas \\
\hline 12 & Munivatul Bagi & 50 & Belum Tuntas \\
\hline 13 & Meylan Saleh & 85 & Tuntas \\
\hline 14 & Maya Supu & 55 & Belum Tuntas \\
\hline 15 & Safitri Putri Karim & 100 & Tuntas \\
\hline 16 & Sintia Kaiko & 75 & Tuntas \\
\hline 17 & Silvian Thaib & 80 & Tuntas \\
\hline 18 & Tasya Matoka & 55 & Belum Tuntas \\
\hline 19 & Inal Tino & 90 & Tuntas \\
\hline 20 & Abdul Zakir Walinga & 70 & Tuntas \\
\hline 21 & Respandi Pakaya & 65 & Belum Tuntas \\
\hline 22 & Fikriyadi Mantulu & 75 & Tuntas \\
\hline 23 & Salwin Helingo & 60 & Belum Tuntas \\
\hline 24 & Haikal Djumaati & 80 & Tuntas \\
\hline 25 & Hazrin Laiya & 50 & Belum Tuntas \\
\hline \multicolumn{5}{r}{ Jumlah } & & 1785 \\
\hline & Rata - rata & & $64 \%$ \\
\hline & Ketuntasan Klasikal & & 40 \\
\hline
\end{tabular}

Berdasarkan daftar nilai hasil belajar di atas menunjukkan jumlah siswa yang mencapai ketuntasan hasil belajar pada siklus I secara klasikal sebanyak 16 orang siswa atau $64 \%$ sedangkan 9 orang siswa atau $36 \%$ tidak tuntas.

Berdasarkan KKM yang di tetapkan di SMP Negeri 1 Buntulia bahwa seorang siswa dikatakan tuntas belajarnya bila memiliki nilai ketuntasan secara individu 70 dan secara klasikal 80\% siswa di kelas tersebut tuntas belajarnya. Oleh karena itu hasil belajar siswa pada siklus I belum mencapai ketuntasan belajar secara klasikal karena hanya mencapai $64 \%$ 
Tabel 6

Refleksi Hasil Belajar Siswa, Kemampuan Guru dan Aktivitas Siswa

\begin{tabular}{|c|c|c|c|}
\hline No & Refleksi & Hasil Temuan & Revisi \\
\hline & Kemampuan Guru & $\begin{array}{l}\text { Kemampuan guru pada siklus I } \\
\text { adalah 78\% yang tergolong cukup, } \\
\text { terdapat beberapa point dalam } \\
\text { pembelajaran yang dikategorikan } \\
\text { cukup yaitu Kemampuan } \\
\text { menyampaikan tujuan pembelajaran } \\
\text { dan menginformasikan tujuan } \\
\text { pembelajaran melalui metode } \\
\text { mind mapping dan kemampuan guru } \\
\text { memberikan pertanyaan kepada } \\
\text { siswa serta kemampuan guru pada } \\
\text { saat mengelola kelas. Dengan } \\
\text { demikian, pada kegiatan } \\
\text { pembelajaran yang masih } \\
\text { dikategorikan cukup harus dilakukan } \\
\text { perbaikan -perbaikan. Dengan } \\
\text { demikian dapat meningkatkan } \\
\text { kemampuan guru dalam proses } \\
\text { pembelajaran untuk siklus } \\
\text { selanjutnya menjadi lebih baik }\end{array}$ & $\begin{array}{l}\text { Untuk pertemuan selanjutnya guru } \\
\text { harus mampu menyampaikan tujuan } \\
\text { pembelajaran dan } \\
\text { mengimformasikan } \\
\text { pembelajaran sebelum pelajaan } \\
\text { dimulai,memberikan pertanyaan } \\
\text { kepada siswa dan memberikan } \\
\text { kesempatan kepada siswa yang lain } \\
\text { untuk menjawab pertanyaan serta } \\
\text { memperhatikan siswa yang dianggap } \\
\text { memperburuk suasana pembelajaran } \\
\text { sehingga penguasaan kelas akan } \\
\text { terkontrol dan pembelajaran berjalan } \\
\text { dengan lancar }\end{array}$ \\
\hline & Aktivitas Siswa & $\begin{array}{l}\text { Aktivitas siswa dalam kegiatan } \\
\text { pembelajaran pada siklus I adalah } \\
67,85 \% \text { yang tergolong kurang, } \\
\text { terdapat beberapa poit yang } \\
\text { dikategorikan cukup yaitu pada } \\
\text { pengerjaan LKS yang diberikan guru } \\
\text { dan presentasi siswa terhadap hasil } \\
\text { tugas kelompok. Dengan demikian, } \\
\text { pada kegiatan pembelajaran yang } \\
\text { masih dikategorikan cukup harus } \\
\text { dilakukan perbaikan - perbaikan } \\
\text { dalam penerapan metode mind } \\
\text { mapping pada pembelajaran Bahasa } \\
\text { Inggris untuk siklus selanjutnya } \\
\text { menjadi lebih baik }\end{array}$ & $\begin{array}{l}\text { Untuk pertemuan selanjutnya } \\
\text { guru harus lebih memperhatikan dan } \\
\text { mengarahkan siswa agar fokus } \\
\text { dan berkonsentrasi dalam } \\
\text { mendengarkan/memperhatikan } \\
\text { penjelasan guru, dalam } \\
\text { menyelesaikan LKS dan } \\
\text { mengarahkan } \\
\text { mempresentasikan hasil } \\
\text { tersebut }\end{array}$ \\
\hline & Hasil Siklus I & $\begin{array}{l}\text { Berdasarkan hasil tes yang dilakukan } \\
\text { pada siklus I terdapat bahwa jumlah } \\
\text { siswa yang mencapai ketuntasan } \\
\text { belajar secara individu sebanyak } 16 \\
\text { orang atau } 64 \% \text {, sedangkan } 9 \text { orang } \\
\text { atau } 36 \% \text { dengan rata - rata hasil } \\
\text { belajar yang diperoleh adalah } 71,40 . \\
\text { Oleh karena itu ketuntasan belajar } \\
\text { siswa belum mencapai ketuntasan } \\
\text { belajar klasikal }\end{array}$ & $\begin{array}{l}\text { Untuk pertemuan selanjutnya guru } \\
\text { harus lebih memperhatikan siswa } \\
\text { serta membimbing siswa pada saat } \\
\text { proses pembelajaran agar hasil } \\
\text { belajar siswa tercapai atau sesuai } \\
\text { dengan yang di harapkan. }\end{array}$ \\
\hline
\end{tabular}

Siklus II

Observasi dilakukan selama proses pembelajaran siklus II berlangsung. Observasi dilakukan terhadap hasil belajar siswa, kemampuan guru dan aktivitas siswa serta mencatat hal - hal yang terjadi selama pelaksanaan pembelajaran 
1) Observasi Kemampuan Guru Siklus II

Pada tahap ini, pengamatan terhadap kemampuan guru menggunakan instrumen yang berupa lembar observasi kemampuan guru. Data hasil observasi kemampuan guru dapat dilihat pada tabel 7 berikut:

Tabel 7

Lembar Observasi Kemampuan Guru Pada Siklus II

\begin{tabular}{|c|c|c|c|}
\hline No & Aspek yang Diamati & Nilai & Keterangan \\
\hline 1 & $\begin{array}{l}\text { Pendahuluan: } \\
\text { Kemampuan melakukan apersepsi kepada siswa } \\
\text { sebelum menyampaikan tujuan pembelajaran }\end{array}$ & 4 & Sangat Baik \\
\hline 2 & $\begin{array}{l}\text { Kemampuan memotivasi siswa dengan } \\
\text { mengemukakan kegunaan materi yang akan } \\
\text { dipelajari }\end{array}$ & 3 & Baik \\
\hline 3 & $\begin{array}{llr}\text { Kemampuan } & \text { menyampaikan tujuan } \\
\text { pembelajaran } & \text { dan menginformasikan } \\
\text { pembelajaran melalui metode mind mapping }\end{array}$ & 3 & Baik \\
\hline 4 & $\begin{array}{l}\text { Kegiatan inti: } \\
\text { Kemampuan menjelaskan materi dengan } \\
\text { menggunakan metode mind mapping }\end{array}$ & 3 & Baik \\
\hline 5 & $\begin{array}{l}\text { Kemampuan memberi kesempatan kepada } \\
\text { siswa untuk bertanya. }\end{array}$ & 3 & Baik \\
\hline 6 & $\begin{array}{l}\text { Kemampuan menghargai berbagai pendapat } \\
\text { siswa }\end{array}$ & 4 & Sangat Baik \\
\hline 7 & $\begin{array}{l}\text { Kemampuan memberikan penguatan kepada } \\
\text { siswa }\end{array}$ & 4 & Sangat Baik \\
\hline 8 & $\begin{array}{l}\text { Kemampuan guru memberikan pertanyaan } \\
\text { kepada siswa. }\end{array}$ & 4 & Sangat Baik \\
\hline 9 & $\begin{array}{l}\text { Kemampuan mengarahkan siswa untuk } \\
\text { menyelesaikan tugas secara kelompok }\end{array}$ & 3 & Baik \\
\hline 10 & Kemampuan guru menguasai kelas & 3 & Baik \\
\hline 11 & $\begin{array}{l}\text { Penutup: } \\
\text { Kemampuan guru menyimpulkan terhadap } \\
\text { materi yang telah diajarkan }\end{array}$ & 4 & Sangat Baik \\
\hline 12 & Kemampuan mengalokasikan waktu & 3 & Baik \\
\hline 13 & Adanya interaksi antara siswa dan guru & 4 & Sangat Baik \\
\hline \multicolumn{2}{|r|}{ Jumlah } & \multicolumn{2}{|r|}{45} \\
\hline \multicolumn{2}{|r|}{ Nilai Presentase } & \multicolumn{2}{|r|}{$86,53 \%$} \\
\hline \multicolumn{2}{|r|}{ Kategori } & \multicolumn{2}{|r|}{ Baik } \\
\hline
\end{tabular}

Berdasarkan Tabel 7 menunjukkan bahwa kegiatan pembelajaran melalui metode mind mapping mendapatkan skor persentase $86,55 \%$ yang termasuk ke dalam kategori baik. Hal tersebut membuktikan bahwa hasil yang diperoleh pada siklus II lebih meningkat dari siklus I. 


\section{2) Observasi Aktivitas Siswa Siklus II}

Pada tahap ini adalah kegiatan mengamati aktivitas siswa pada saat pembelajaran berlangsung, dari awal sampai akhir untuk sertiap pertemuan. Hasil pengamatan aktivitas siswa pada RPP II dapat dilihat pada tabel 8 berikut:

Tabel 8

Lembar Observasi Aktivitas Siswa Siklus II

\begin{tabular}{|c|c|c|c|}
\hline No & Aspek yang Diamati & Nilai & Keterangan \\
\hline 1 & Mendengarkan/memperhatikan penjelasan guru & 4 & Sangat Baik \\
\hline 2 & $\begin{array}{l}\text { Mengajukan pertanyaan yang berhubungan } \\
\text { dengan materi }\end{array}$ & 3 & Baik \\
\hline 3 & Antusias siswa dalam belajar & 3 & Baik \\
\hline 4 & Pengerjaan LKS yang diberikan oleh guru & 3 & Baik \\
\hline 5 & Presentasi siswa terhadap hasil tugas kelompok & 3 & Baik \\
\hline 6 & $\begin{array}{l}\text { Menarik kesimpulan tentang materi yang telah } \\
\text { diajarkan }\end{array}$ & 3 & Baik \\
\hline 7 & $\begin{array}{l}\text { Perilaku yang tidak relevan dengan KMB } \\
\text { Seperti: melamun, jalan - jalan di kelas, } \\
\text { membaca buku/mengerjakan tugas mata } \\
\text { pelajaran lain, bermain - main dengan teman dan } \\
\text { lain - lain }\end{array}$ & 3 & Baik \\
\hline \multicolumn{2}{|r|}{ Jumlah } & \multicolumn{2}{|r|}{23} \\
\hline \multicolumn{2}{|r|}{ Nilai Presentase } & \multicolumn{2}{|r|}{$82,14 \%$} \\
\hline \multicolumn{2}{|r|}{ Kategori } & \multicolumn{2}{|r|}{ Baik } \\
\hline
\end{tabular}

Berdasarkan data di atas, terlihat jelas aktivitas siswa pada pembelajaran Bahasa Inggris melalui metode mind mapping pada siklus II mengalami peningkatan sebesar 14,29 \% dari siklus sebelumnya yang masih termasuk dalam kategori kurang yaitu dengan nilai persentase $67,85 \%$ menjadi meningkat pada siklus II yaitu dengan nilai persentase $82,14 \%$ yang termasuk kedalam kategori baik.

3) Hasil belajar Siswa Pada Siklus II

Setelah berlangsungnya proses belajar mengajar pada RPP Siklus II untuk mengetahui ketuntasan belajar siswa, dengan kriteria ketuntasan minimal yang diterapkan di SMP Negeri 1 Buntulia minimal 70. Hasil tes belajar pada Siklus II pada dapat dilihat pada tabel 9 berikut. 
Tabel 9

Daftar Nilai Hasil Belajar Siswa Siklus II

\begin{tabular}{|c|l|c|c|}
\hline No & \multicolumn{1}{|c|}{ Nama } & Nilai & Keterangan \\
\hline 1 & Aslan Djumaati & 100 & Tuntas \\
\hline 2 & Abd Rahim Goi & 85 & Tuntas \\
\hline 3 & Audi Masayu Dauna & 70 & Tuntas \\
\hline 4 & Bunga Bajuani & 90 & Tuntas \\
\hline 5 & Deis Balu & 100 & Tuntas \\
\hline 6 & Elsa Tantu & 85 & Tuntas \\
\hline 7 & Fitri Hulopi & 80 & Tuntas \\
\hline 8 & Ingki Umar & 60 & Belum Tuntas \\
\hline 9 & Indri Umar & 75 & Tuntas \\
\hline 10 & Kasim Bagi & 80 & Tuntas \\
\hline 11 & Lutvia Adam & 90 & Tuntas \\
\hline 12 & Munivatul Bagi & 60 & Belum Tuntas \\
\hline 13 & Meylan Saleh & 85 & Tuntas \\
\hline 14 & Maya Supu & 100 & Tuntas \\
\hline 15 & Safitri Putri Karim & 85 & Tuntas \\
\hline 16 & Sintia Kaiko & 100 & Tuntas \\
\hline 17 & Silvian Thaib & 75 & Tuntas \\
\hline 18 & Tasya Matoka & 90 & Tuntas \\
\hline 19 & Inal Tino & 85 & Tuntas \\
\hline 20 & Abdul Zakir Walinga & 70 & Tuntas \\
\hline 21 & Respandi Pakaya & 75 & Tuntas \\
\hline 22 & Fikriyadi Mantulu & 70 & Tuntas \\
\hline 23 & Salwin Helingo & 90 & Tuntas \\
\hline 24 & Haikal Djumaati & & Jum Tuntas \\
\hline 25 & Hazrin Laiya & & \\
\hline & & & 8030 \\
\hline & & & \\
\hline & Kata - rata & & \\
\hline
\end{tabular}

Berdasarkan hasil belajar di atas menunjukkan jumlah siswa yang mencapai ketuntasan hasil belajar pada siklus II secara klasikal sebanyak 22 orang siswa atau $88 \%$ sedangkan 3 orang siswa atau 12\% tidak tuntas. Berdasarkan KKM yang di tetapkan di SMP Negeri 1 Buntulia bahwa seorang siswa dikatakan tuntas belajarnya bila memiliki nilai ketuntasan secara individu 70 dan secara klasikal 80 $\%$ siswa di kelas tersebut tuntas belajarnya. Dengan demikian dapat disimpulkan ketuntasan hasil belajar siswa melalui penerapan metode mind mapping pada siklus II mengalami peningkatan dan telah mencapai ketuntasan belajar klasikal

Tercapainya keberhasilan belajar ini tidak terlepas dari usaha guru dalam memotivasi siswa. Dimana pada setiap siklus, guru menyiapkan berbagai keperluan siswa serta guru selalu membimbing siswa pada setiap kelompok untuk membuat mind mapping bertujuan agar siswa lebih aktif ketika proses pembelajaran yang bisa menggali pengetahuan mereka terhadap apa - apa yang telah dipelajari. 
Pembelajaran dengan menggunakan mind mapping dilengkapi dengan media gambar dan warna - warna yang menarik sehingga siswa menjadi semangat dan tertarik dalam membuat mind mapping.

Berdasarkan uraian di atas pada siklus II tidak ada lagi kendala-kendala yang dihadapi pada siklus I, ini dibuktikan dari hasil belajar siswayang telah meningkat. Sehingga dapat disimpulkan bahwa pembelajaran dengan menggunakan metode mind mapping dapat meningkatkan hasil belajar siswa kelas VII B SMP Negeri 1 Buntulia

\section{PENUTUP}

Berdasarkan hasil penelitian yang penulis laksanakan tentang penerapan metode mind mapping untuk meningkatkan hasil belajar siswa kelas VII B SMP Negeri 1 Buntulia dapat dikemukakan kesimpulan dan saran - saran sebagai berikut: 1. Aktivitas guru selama proses pembelajaran dengan menggunakan metode mind Mapping, siklus I mencapai kategori cukup dengan persentase $78 \%$ dan pada siklus II mengalami peningkatan menjadi $87 \%$ dengan kategori baik

2. Aktivitas siswa selama proses pembelajaran dengan menggunakan metode mind mapping, pada siklus I mencapai kategori cukup yaitu $68 \%$ dan pada siklus II mengalami peningkatan menjadi $82 \%$ yang termasuk kedalam kategori baik

3. Peningkatan hasil belajar siswa setelah menggunakan metode mind mapping pada siklus I tingkat ketuntasan belajar siswa secara klasikal telah mencapai $64 \%$ dari KKM yang telah diterapkan yaitu $80 \%$. Dan terjadi peningkatan pada siklus ke II hingga mencapai $88 \%$. Dengan demikian dapat disimpulkan bahwa siklus I dan II telah mencapai KKM yang telah diterapkan yaitu $80 \%$.

\section{DAFTAR PUSTAKA}

Arikunto, Suharsini. 2010. Prosedur Penelitian Suatu Pendekatan Praktek. Jakarta: Rineke Cipta

Bobbi Deporter dkk. 2004. Quantum Teaching. Bandung: Mizan Puataka

Depdiknas. 2006. Kurikulum Tingkat Satuan Pendidikan. Jakarta. Depdiknas

Dimyati, Mudjion. 2010. Belajar dan Pembelajaran. Jakarta: PT. Rineke Cipta

Dyah Retno. 2011. Cara Instan Melatih Daya Ingat. Jakarta: Agogos Publishing

Echols, John dan Hasan Shadily. 2003. Kamus Inggris-Indonesia. Jakarta: PT Gramedia Pustaka Utama

Jamil, Suprihatiningrum. 2013. Strategi Pembelajaran Teori dan Aplikasi. Jogjakarta: Ar - Ruzz Media

M. Junaidi Ghony. 2008. Penelitian Tindakan Kelas. Malang: UIN Malang Press 
Nana Sudjana. 2002. Penilaian Hasil Proses Belajar Mengajar. Bandung: Rasdakarya

Slameto. 1995. Belajar dan Faktor - Faktor yang Mempengaruhinya. Jakarta: Rineka Cipta

Sugiarto, lwan. 2004. Mengoptimalkan Daya Kerja Otak dengan Berpikir Holistik dan Kreatif. Jakarta: Gramedia

Suprihatiningrum, Jamil. 2013. Strategi Pembelajaran Teori dan Aplikasi. Yogyakarta : AR-RUZ MEDIA

Tony Buzan. 2006. Buku Pintar Mind Mapping. Jakarta: Gramedia Pustaka Utama 
